\title{
COOPERATION BETWEEN NATO AND THE EUROPEAN UNION FOR SHAPING INTERNATIONAL SECURITY
}

\begin{abstract}
Efficient shaping of international security depends on the activity of numerous entities, particularly on the functioning of organizations such as NATO and the European Union. The article presents the contribution of these unions of democratic states to global peace-building and indicates the desired directions of transformation aimed at developing their power, solidarity and credibility. These are the factors that condition the organizations' central role in shaping Euro-Atlantic and global security. Attention has been also paid to the need for strengthening cooperation between these organizations, which results from new, complex challenges and threats emerging in the currently very unstable security environment, which could not be dealt with by NATO and even less by the EU on their own. Thanks to close cooperation, the organizations have more possibilities and resources to react to various crisis situations as well as they can achieve the desired effect of synergy. Thus power and effectiveness of the EU and NATO is conditioned by their common and consistent security policy.
\end{abstract}

\section{Key words}

European Union, NATO, threats, security policy, strategy, missions, operational capabilities, transformation, cooperation 


\section{Introduction}

The contemporary environment of international security is dynamic, variable and complex, which makes it difficult to forecast its possible development. Apart from traditional military threats whose scale is now much smaller than in the $20^{\text {th }}$ century (Huzarski, 2009, p. 22), there has been increasing emergence of non-military threats that are of far more important nature and have greater influence than in the past. Thus apart from the military-political security threats, there are now dangers in such areas as politics, economy, science and technology, ideology, culture, as well as dangers related to issues of humanitarian, social and ecological nature. (Dawidczyk, 2001, p. 17). It should be noted that contemporary security environment is characterized also by blurring of the boundary between its military and non-military dimensions (Strategia..., 2014, p. 17). The catalogue of threats that are currently observed or that can appear in the future is continuously expanding, and is characterized by its variety, great intensity and scope of influence as well as unpredictability of its scale and effects. Therefore solving a plethora of problems that are present in the contemporary world requires complex and coordinated actions on both global and regional levels as well as engagement of many different entities of international relations, not only states, particularly superpowers, but also international organizations such as NATO or the European Union (the EU). The increase in importance and prestige of these organizations, combined with their intensive activity, can effectively shape the architecture of international security in the $21^{\text {st }}$ century through counteracting and combating various threats of both military and non-military nature. What comes as important is integration and consolidation of the areas of their activity and efforts, achieved mainly through following a common and consistent security policy, which is a prerequisite for the desired effect of synergy and thus greater effectiveness of these organizations.

\section{Characteristics of NATO and the European Union as leading organizations of international security}

Since it was established (1949), the North Atlantic Treaty Organization (NATO) has considered ensuring freedom and security to all of its member states as its primary goal, to be achieved by political and military means. NATO is therefore 
an international organization of a military-political character and at the same time an allied bloc security system. What is of particular importance for the interests of its member states is Article 5 of the North Atlantic Treaty (the Washington Treaty) - a legal document which is the base for NATO's activity. The Article says that an external armed attack against one or more of its member states shall be considered an attack against the organization. This casus foederis formula is a particular expression of military solidarity between the members of the Alliance ${ }^{1}$. The system of NATO's activity is based on the rule that common security of the member states is indivisible, which means that:

- no member state has to rely exclusively on its own national defence and economic resources to counteract threats to its security; it can rely on the support of NATO states-parties;

- no member state shall withdraw from its alliance obligations towards the other states in case of threat to their security.

The Alliance is a unique community, a great family of (currently) 29 EuroAtlantic states which share values such as liberty, democracy, rule of law, and human rights. According to the resolutions of the Treaty, each member state is obliged to maintain peace and security as well as develop amicable international relations.

NATO's aims and tasks as well as the method of their realization until the end of the second decade of the $21^{\text {st }}$ century were stipulated in the NATO new Strategic Concept, adopted during the 22nd summit in Lisbon, held on 19-20 November 2010. The Alliance's core tasks included collective defence, crisis management (counteracting crises), and cooperative security. Collective defence of the territory of the Alliance was considered the pillar of NATO. It is a foundation indispensable for coherence and effectiveness of the Alliance. Crisis management is related to the employment of political and military tools in order to manage developing crises and conflicts which are outside the Alliance borders but have the potential to affect its security. Cooperative security is achieved through activities aimed at strengthening international security, including partnerships with relevant states and other international organizations; active contribution to arms control, non-proliferation and disarmament; and "keeping

1 The term "alliance" in lexicon publications is defined as "a bilateral or multilateral international agreement, in which the parties oblige to provide mutual aid in a situation defined by them". See: Wielka encyklopedia PWN, Warszawa 1976, p. 576. In turn, casus foederis means a situation (defined in the alliance) that causes (imposes) an obligation to provide aid. 
the door to membership in the Alliance open to all European democracies that meet NATO's standards" (cf. NATO, 2010). Security and defense policy of NATO is based on joining its member states' military, political and economic potentials to achieve common goals. What remains the foundation of NATO's operational capabilities is the nuclear and conventional power of the US, which is the most important guarantee of Euro-Atlantic security (Czulda, 2013).

During the 70 years of its existence, NATO has developed efficient procedures of functioning both in the political and military context; it also has substantially contributed to building international security. After the end of the Cold War and the beginning of political and system transformations in the states of Central and Eastern Europe, the Alliance extended its competence. At the beginning of the 1990s, it pledged to support peace operations conducted under the auspices of the United Nations or other security organizations, also those beyond the scope of its responsibility stipulated in the Washington Treaty ${ }^{2}$. This increased NATO's ability to influence international security. Since 1991 the Alliance's member states have participated in 35 military or civil-military missions conducted outside Article 5, mainly in the territory of states faced with crises or armed conflicts. Their aim was to establish peace and stabilize situations as well as combat international terrorism and provide humanitarian aid. The greatest and most important operations have been conducted by the Alliance in the Balkans, involving the Implementation Forces (IFOR) and the Stabilization Forces (SFOR) in Bosnia and Herzegovina, the Kosovo Force (KFOR) in Kosovo; there were also the Operation International Security Assistance Force (ISAF) in Afghanistan and the Operation Unified Protector in Libya.

The turbulent and unpredictable contemporary security environment forces NATO to keep evolving so that it increases its ability of effective reaction to new challenges and threats of the $21^{\text {st }}$ century. The organization should aim at transforming from the alliance of political-military nature to a wide consultation and cooperation forum of various entities, tasked with broad-based world security. Global challenges and threats require global approach, so NATO should be open to dialogue, cooperation and partnership with other countries and international organizations such as the European Union.

2 Resolutions on providing support in the implementation of peacekeeping missions conducted under the authority of the UN Security Council were made in the so-called London Declaration, which was a result of talks between heads of states and government representatives of NATO member states in July 1990. Detailed assumptions were adopted at the North Atlantic Council meeting in Brussels in January 1994. 
The European Union (the EU) was founded on the basis of the Treaty on European Union (the Maastricht Treaty) in 1992, which came into force the following year. The Treaty established the Common Foreign and Security Policy (CFSP), whose role was to include all issues related to the EU's security, including the gradual formulation of common defense policy as well as establishment of common defense in the future ${ }^{3}$. What was agreed upon as the integral part of CFSP was the common security and defence policy, which was to ensure the EU's operational capability based on the civil and military means of its member states. The EU intended to use them in their activities conducted outside its territory, in compliance with the Charter of the United Nations, such as missions aimed at peacekeeping, conflict prevention, and strengthening of international security.

What had a great influence on adapting the EU to new challenges and threats of the $21^{\text {st }}$ century was the Lisbon Treaty ${ }^{4}$, signed in December 2007. Its aim was to strengthen the power democracy as well as the efficiency and dynamics of the organization's activities, which would result in better preparation of the EU to new global threats and challenges. Also the EU's competence related to CFSP was extended. The Lisbon Treaty for the first time introduced a clause on common defence, which connects the EU's member states in a particular way. It means that any member state attacked in its own territory can count on support of the other states obliged to provide aid ${ }^{5}$. The member states can participate in military and humanitarian missions (undertake operational activities), also in third states. Their primary goal is to maintain peace and strengthen international security. These activities are based on civil and military means provided by EU states. The assumptions and scope of the so-called EU

3 The Treaty on the European Union was signed in 1992 by the following countries: Belgium, Denmark, France, Greece, Spain, the Netherlands, Ireland, Luxembourg, Germany, Portugal, Great Britain and Italy. Article 42 section 7 stated that: "If a Member State is the victim of armed aggression on its territory, the other Member States shall have towards it an obligation of aid and assistance by all the means in their power, in accordance with Article 51 of the United Nations Charter".

4 The Lisbon Treaty was signed by the leaders of the 27 Member States. It came into force on December 1, 2009; the treaty was introduced instead of the rejected Constitution for Europe. It assumed the reform of EU institutions, so it is also called the Reform Treaty. The Treaty gives the European Union legal personality and makes the European Union the successor of the European Community.

5 The clause has exceptions. First, it does not influence the security and defense policy of neutral member states, which can still keep their neutrality. The second exception is that the clause does not apply to commitments undertaken within NATO framework. 
Petersberg missions were expanded. Apart from the existing humanitarian and rescue missions, peacekeeping missions and armed missions aimed at handling crisis situations, additional actions were introduced, including common disarmament operations, military advisory and support missions, conflict prevention and peacekeeping missions, as well as peace-restoration and stabilization missions following the end of a conflict.

The EU is an example of a cooperative security system, currently treated as most efficient and appropriate for contemporary demands. This system is based on the assumption that close cooperation of states as well as their enhanced connectivity not only of military but also economic, political, legal and cultural nature will create a situation in which using force in order to achieve goals of national policy will become impossible or very unlikely. The system stresses the need to prevent crises in interstate relations, and should they occur, they ought to be solved through amicable tools. It must be emphasized that since its foundation the EU has made significant contribution to the process of keeping and strengthening international security through conflict prevention, responding to crises, supporting democracy and international legal system, as well as protecting human rights and civil freedoms. In response to threats to international or regional security, the EU has launched and still undertakes various autonomous civil and military operations. So far over 70 thousand soldiers and civil staff, delegated mainly but not exclusively by the member states, participated in over $30 \mathrm{EU}$ peacekeeping missions conducted on three continents. Those missions were of various nature, e.g. restoring and maintaining peace operations (EU NAVFOR Atalanta Somalia, Concordia in the former Yugoslav Republic of Macedonia, EUFOR Althea Bosnia and Herzegovina); operations regarding the improvement of the rule of law (EUJUST LEX Iraq and EULEX Kosovo); police missions (EUPM Bosnia and Herzegovina, EUPOL the Democratic Republic of the Congo, EUPOL COPPS and EUPOL Afghanistan); observation missions (EUMM Georgia); training and advisory missions (EUBAM Rafah, EUTM Mali); missions supporting security sector reform (EUSEC the Democratic Republic of the Congo, UERSB Guinea-Bissau).

It should be noted that the scope of EU activity is continuously expanding, which results i.a. from agreements signed with the UN, OSCE, and first of all with NATO. The organization is governed by three strategic priorities, i.e. responding to conflicts and external crises, building capabilities of the member states and protecting the community's citizens. Participation in missions is an important operational, but above all political value. Therefore the EU should be more involved in crisis management and thus take even greater responsibility 
for international security. The organization has enormous potential and thus can significantly contribute to the work of building peace and global order.

\section{The origins and development of the transatlantic partnership}

What is necessary to counter the multiple and increasingly complex challenges and threats of today's world is close and effective cooperation not only between states but also the largest international organizations which deal with the issue of security in its broad sense. Undoubtedly, NATO and the EU are such organizations. These entities are particular partners due to the fact that they share strategic interests and such values as democracy, liberty, sovereignty, civil rights and freedoms. Moreover, the vast majority of EU countries (22 out of 28) are also members of the North Atlantic Alliance. Therefore these organizations should complement as well as support each other in their activities aimed at maintaining peace and security not only in the transatlantic space but in all corners of the globe.

The political and formal-legal basis of the EU-NATO strategic partnership has evolved since the EU was founded, particularly since the organization adopted an autonomous security and defence policy. There are four main phases of mutual cooperation. The first period is marked with the Maastricht Treaty coming into force in 1993. The new situation that developed after the dissolution of the Soviet Union, the fall of the Warsaw Pact and the entire Eastern Bloc caused the need for greater engagement of European states in ensuring security of the region, particularly with regard to the conflict that broke out in the Balkans. For this reason, EU members decided to introduce a common security and defence policy. Over time, they began to strive for development of its institutional and operational capabilities to conduct joint operations in crisis situations as well as for collective defense. Thus the EU entered the area of competence previously held by NATO. A partial solution to this complicated situation was the agreement concluded at the North Atlantic Council summit in Brussels in 1994, settling the dispute between the transatlantic community regarding the European Security and Defence Identity (ESDI) ${ }^{6}$. It was agreed that the Western European Union (WEU), as an autonomous security organization

6 European Security and Defence Identity is a conception of security policy of the states of the European Community, which was formulated in the 1980s within the Western European Union. 
of Western Europe, would constitute the European pillar of NATO, and at the same time an armed branch of the EU. During the 1996 NATO summit in Berlin, the acceptance of the development of ESDI was confirmed, and it was agreed that NATO would make its resources available for EU needs, particularly during peacekeeping operations conducted by the WEU. This was a significant step towards restoring a balanced division of responsibility between NATO and the EU. At the subsequent NATO summit in Washington in 1999, the basic principles of EU-NATO relations were formulated. The final communiqué said that NATO and the EU should establish mutual consultations, cooperation and transparency. Summarizing the first stage of EU-NATO relations, it should be stated that it is perceived more in terms of competition than cooperation between the two organizations.

The second phase of cooperation began with the new millennium. It is referred to as formalization because the organizations tried to develop clear and effective methods of cooperation. The scope of cooperation and the ways of holding joint consultations on security issues were defined in January 2001 as part of the official exchange of letters between NATO Secretary General and the EU Presidency (Lis, 2016). At the European Council summit in Leaken in December 2001, it was announced that the EU intended to conclude final arrangements with NATO regarding the issues of security and to conclude agreements on ensuring its access to the Alliance's operational planning system, establishing the rules for making NATO's pre-defined assets and potential available to the EU as well as for command options. These agreements were identified as necessary for European security and defence system as well as for enhancement of EU capabilities to conduct crisis management operations (Wnioski Prezydencji..., 2001). In December 2002, the NATO-EU Declaration on the European Defence and Security Policy was adopted. It was one of the most important documents related to the strategic partnership between the organizations. The Declaration recognized that the mutual relations would be based on such political principles as partnership, transparency, equality and balance, respect for decision-making autonomy as well as on the interests of the organization and its members, transparent development of military capabilities common to the Alliance and the EU that would ensure mutual strengthening. What had a great significance for determining the formal grounds and framework of cooperation between the EU and NATO was the Berlin Plus ${ }^{7}$ package of agreements, finalized in March 2003,

7 The name refers to the agreements adopted during the NATO Berlin summit in June 1999. The Berlin Plus agreement is a package of 1547 institutional agreements (mostly 
which enabled the EU to use NATO military forces and resources during its own operations as well as provided the EU with access to the Alliance's operational planning units, including NATO's European command. The parties also agreed on procedures of consultations related to the EU's missions where the Alliance's resources and capabilities would be used. Furthermore, the availability of options for the European command within NATO was increased, and the Alliance's defence planning system was adjusted to take into account the availability of forces and resources for operations conducted by the EU. The agreements ensured mutual consultations on operations conducted following the Berlin Plus formula as well as coordination of the development of the partners' military potential. The Berlin Plus agreements initiated changes also in the institutional area. In 2005 the NATO Permanent Liaison Team was established at the Military Staff of the European Union, and in 2006 a similar EU unit was established at the Supreme Headquarters Allied Powers Europe (SHAPE). Despite the great significance of the Berlin Plus agreements, the actual needs for cooperation between the organizations went beyond the adopted arrangements, which was evidenced by the missions conducted simultaneously by the EU and NATO in Kosovo and Somalia's coastal waters. Although both of the organizations had a similar mandate and the missions were conducted in the same region, the coordination of actions and the exchange of intelligence information did not work between the EU and NATO. This necessitated adopting informal collaboration tools, such as personal arrangements between mission commanders, which was a prerequisite for increasing the security of military and civil staff. However, further agreements on the extension of cooperation scope were hindered due to divergences between the member states, which intensified in 2004 .

The crisis in EU-NATO relations (also the institutional ones) initiated the third phase of cooperation, referred to as normalization through deformalization of mutual relations (Lis, 2016). The situation was mainly caused by the intervention of US troops and coalition forces in Iraq in 2003 as well as by the dispute between Turkey and Cyprus ${ }^{8}$, which made it impossible for the organizations to exchange

informal) concluded between the EU and NATO. They determine i.a. the principles of safe exchange of information as well as the procedures of making use of NATO's resources and capabilities.

8 The reason for the conflict between the allies was Cyprus accession to the EU in 2004. As a result, Turkey blocked Cyprus signing a technical agreement on exchange of secret information, while Cyprus opposed Turkey taking part in the European Defence agency. 
secret information (also intelligence information), hindered the organization of meetings on strategic cooperation, and impeded the coordination of operations conducted in the same territory (Terlikowski \& Chapell, 2011). A political barrier to mutual cooperation was also the divergences between EU member states regarding the development and the degree of autonomy of the common defense and security policy, as well as the significance of transatlantic ties, including the role of NATO in ensuring European security. What can be recognized as an additional factor obstructing mutual contacts is the overly complicated decision-making and organizational process adopted for EU-NATO cooperation. A measure applied with the intention to break the political impasse in the area of synchronization of the EU's and the Alliance's efforts was the establishment of the EU-NATO Capability Group in 2003. Its task was to ensure coherence and mutual support in the development of the EU's and NATO's operational capabilities. Moreover, the working cooperation at various levels was expanded. Apart from the meetings between the EU High Representative for Foreign Affairs and Security Policy and NATO Secretary General, the recurrent meetings between the North Atlantic Council and the EU Political and Security Committee were also held. Moreover, regular contacts were maintained between representatives of NATO's International Military Staff, the General Secretariat of the Council of the European Union, the EU Military Staff (EUMS), and the European Defence Agency (EDA). In order to increase the complementarity of research projects and to avoid duplication of efforts and costs, contacts between the European Defence Agency and the Allied Command Transformation were developed. Hope for improvement in formal cooperation between NATO and the EU also rested on the 2007 Lisbon Treaty; however, its provisions did not have much impact on mutual relations. It was only in December 2013 that the European Council held a debate on security issues, during which actions aimed at increasing EU-NATO cooperation were determined. It was stated that the development of common security and defence policy should be complementary to NATO operations; however, with respect to the procedural and decision-making autonomy of the parties. It was assumed that common security and defence policy would strengthen European security as well as contribute to peace and stability in the EU's neighbor countries. Unfortunately, as early as in 2014 it turned out that in the face of aggressive activities of the Russian Federation in Ukraine, the EU was not able to react adequately. However, it must be said that the new political conditions, particularly the fact that there had been a real threat from Russia, positively influenced the dynamics of changes in EU-NATO relations, which entered the fourth phase, referred to as retightening of cooperation between 
the two organizations. Currently, this cooperation is highly dynamic, which is described in the final part of this article.

\section{Joint initiatives of the European Union and NATO in the field of security}

The two organizations have been incessantly (however, with various intensity) cooperating in the area of peace and security since the EU was founded. Their reaction to Russia's actions in Ukraine in 2014 is considered a particular testimony to effectiveness of this cooperation. The European Union imposed severe economic sanctions against the Russian Federation; in turn, NATO supported those sanctions and at the largest scale since the end of the Cold War strengthened the collective defence capabilities of European countries, particularly those neighboring Russia. In the face of a real threat, the intensity of political and military cooperation between the EU and NATO also increased significantly ${ }^{9}$.

Up to that moment, EU-NATO cooperation had aimed mainly at preparing and conducting various military and civil operations in regions where crisis situations emerged. Joint actions on such a significant issue as international security strongly influenced the process of strengthening their mutual relations. The conducted actions were usually based on the UN Security Council resolutions and the joint agreements concluded between the EU and NATO.

The first EU military operation that facilitated the implementation of the Berlin Plus agreements was the Concordia mission, conducted in the former Yugoslav Republic of Macedonia. It replaced NATO's peacekeeping mission Allied Harmony, whose aim was to ensure implementation of and compliance with the Ohrid agreement, which ended the conflict between the Yugoslav Republic of Macedonia and Albania. The activities of EU forces, in which 300 soldiers took part, began on March 31, 2003 and lasted until mid-December of the same year. During this mission, the EU used the resources and capabilities of the Alliance, which was possible thanks to the arrangements of the Berlin Plus agreement. The operation showed that the NATO-EU cooperation in security

9 At 2016 NATO summit in Warsaw, the Secretary General of NATO Jens Stoltenberg stated that the partnership between NATO and the EU was gaining new meaning and a historical decision was made that would allow them to cooperate even more closely. He cited the fact that more agreements had been made over the preceding six months than over the previous 13 years as a proof of developing cooperation, and went on to claim that it was time to elevate this cooperation to a higher level. 
entered a practical dimension. It also confirmed the EU's ability to conduct small-scale military operations. The experience that the EU gained from this mission allowed the organization to prepare for the next, even more complex, peacekeeping operation Althea, also conducted in the Balkans. The contingent sent by the member states was 7,000 soldiers and in December 2004 replaced NATO's stabilization force SFOR. The mission's goal was to supervise adherence by the conflicted parties (Serbia, Croatia and Bosnia) to the Dayton Peace Agreement of 1995, which ended the war in former Yugoslavia. As in the previous operation, EU units used NATO's resources and capabilities.

Another mission conducted in the Balkans was EULEX Kosovo, believed to be one of the largest civilian missions of the EU, which started at the beginning of 2008 and aimed at providing support to the authorities of independent Kosovo during the establishing of the rule of law, judiciary system, police forces and customs. At that time, NATO forces (KFOR) were responsible for maintaining security in Kosovo, according to UN Security Council Resolution 1244 of 1999. Although the tasks performed by the Alliance were different from the Union's, the parties agreed on the principles of cooperation, particularly on the ground. The principles provided guidelines to responding to riots, border control, military support for civilian operations, exchange of information, and training of Kosovo policemen. This was an example of a coherent policy of these organizations, thanks to which security in Kosovo improved significantly.

The EU was also involved in activities focused on maritime security. Operation NAVFOR Atalanta was its first activity in this field. Launched at the end of 2008, the mission was to ensure shipping safety by preventing and suppressing acts of piracy in Somali territorial waters. Therefore it served to protect the member states' commercial interests, and its geopolitical goal went far beyond the external borders of the EU. At that time similar actions were also taken by NATO as part of the Allied Provider operation. Although NATO and EU operations were conducted separately, independently of the Berlin Plus agreement, they were an unquestionable contribution to the development of EU-NATO relations aimed at ensuring maritime security. The experience of that mission made the EU adopt in 2014 the Maritime Security Strategy (EUMSS) - a plan which stressed the significance of cooperation on maritime security with other entities and international partners, particularly with NATO and the UN.

NATO and the EU also engage in various, often joint activities to maintain maritime security in the Mediterranean Sea. One of such activities is the military operation EU NAVFOR Med Sophia, established in 2015 and tasked with searching, seizing or turning back vessels that might smuggle migrants. After the 2016 
Warsaw Summit of NATO, these EU activities gained support of the Alliance which launched operations as a part of the SEA GUARDIAN NATO mission. Thanks to this, the activities of smuggling groups were notably curbed and many tragedies were avoided. These examples prove that also in maritime security the EU and the Alliance complement one another.

To summarize, it should be noted that the EU and NATO often conducted autonomous military and civilian operations in the same region and with a similar purpose. However, formal ties between the mission leaderships were not always functioning, which most often was caused by political restrictions resulting from e.g. emphasizing the issue of each organization's autonomy. Due to that, during the operation it was necessary to develop informal mechanisms that ensured institutionalization of cooperation and thus positively influenced its proper functioning. In order to improve the cooperation, the EU and NATO created and improved a structure within their respective command system, particularly a network of connections between the commands responsible for strategic planning, which facilitated the coordination of joint operations. Political control and strategic command over EU missions was held by the Political and Security Committee, while the Military Committee monitored the correct realization of the mission.

The joint operations were an example of practical implementation of provisions included in previous agreements between the organizations, mainly in the Berlin Plus agreement. Thanks to this agreement, during the peacekeeping operations (e.g. Concordia and Althea) the EU could use NATO's military resources, capabilities and planning data, while the Alliance could use the EU's civilian and police resources. It should also be noted that the EU is becoming an increasingly active participant in global security activities and has the capacity to respond to crises. Although so far the EU's activities have been limited, they have undoubtedly contributed to shaping international security.

\section{New areas and prospects for cooperation}

Building international security effectively requires further increased and coherent cooperation between the EU and NATO. The organizations should approach security issues comprehensively, defining the most important tasks in this field. Potential areas of future cooperation were identified during the North Atlantic Council meeting in December 2015. It was agreed that apart from cooperation in strengthening the resilience of states in the African and Middle East region 
and in counteracting hybrid threats, the area of cooperation will also include developing the capabilities of the EU and NATO members (Ignatiuk, 2016).

The need to strengthen cooperation and coordination of security activities was also highlighted in the 2016 Global Strategy on foreign and security policy for the EU as well as in the joint declaration on EU-NATO cooperation signed during the Warsaw NATO summit in July 2016. These documents defined how organizations can jointly respond to current and future security challenges and threats.

The new EU strategy assumes closer transatlantic cooperation. The EU intends to invest in strong ties with NATO, which help strengthen their resilience and resolve conflicts. The partnership with the Alliance will be strengthened through coordinated development of defense capabilities, joint exercises, activities aimed at building the ability to counteract hybrid and cybernetic threats, and promoting maritime safety. Cooperation in security will primarily concern activities related to crisis management, combating terrorism, cyberspace, migration, energy and climate. The US will remain a global partner of the EU. The organization aims to form with the US a Transatlantic Trade and Investment Partnership (TTIP), which is an expression of commitment to shared values ${ }^{10}$. The EU also intends to intensify political dialogue and cooperation for disarmament, non-proliferation, arms control and combating organized crime.

In turn, the 2016 joint declaration on EU-NATO cooperation should be regarded as an attempt to invest mutual cooperation with fresh impetus. The declaration repeated political principles of strategic partnership and specified the key areas of mutual cooperation between the organizations. This is the first document which made the parties decide to strengthen cooperation, particularly in the following areas (Council Conclusions..., 2016):

1. Countering hybrid threats - building resilience, analytical cooperation in prevention and early detection, information sharing, joint exercises with elements characteristic of hybrid threats, joint activities in strategic communication, and preparation of coordinated cooperation procedures.

2. Operational cooperation including maritime issues - strengthening cooperation, coordination and synergy between operations conducted by NATO and the EU on the Mediterranean Sea and the Aegean Sea in order to ensure maritime security (countering illegal migration and terrorism).

10 Transatlantic Trade and Investment Partnership (TTIP) is a trade agreement that has been negotiated between the EU and the US since 2013. Its main objective is creation of a free trade zone. 
3. Cyber security and defence - joint analysis, prevention and detection, information sharing (including intelligence information) and strengthening cooperation in research innovation and technology regarding cyber defence.

4. Defence capabilities - creating and developing coherent, complementary and interoperational defence capabilities. The member states have common potential that can be used in various configurations during operations conducted by the organizations. Their operational capabilities should be developed in the multinational dimension and reinforced by relevant procedures applied by the EU and NATO. The procedures should also take cognizance of the nature and scope of responsibility of these institutions. It is also significant to strive through closer staff contacts for greater consistency in multinational actions and the results of NATO's defense planning process as well as the EU's capability development plan. The organizations will also be moving towards complementarity of multinational programs developed as part of NATO and EU smart defence. This particularly applies to areas of common interest, such as air transport, cyber defense, satellite communications, and remotely controlled unmanned air systems. It is also planned to enhance interoperability through increased interaction and harmonization of standardization-related activities. Developing and maintaining defence capabilities requires both new investments and optimization of resource use.

5. Defence industry and research - developing the defence industry, intensifying research on defence, developing dialogue between EU and NATO staff on industrial aspects, and enhancing cooperation on defence-related $\mathrm{R} \& \mathrm{~T}$ in common areas of interest.

6. Exercises - led by NATO or the EU, mainly related to crisis management, should include a hybrid element.

7. Defence and security capacity-building - "cooperation, including on the ground, on building partners' capacity and resilience, in particular in the Western Balkans, the Eastern and Southern Neighbourhoods, including Georgia, Republic of Moldova, Ukraine (...)" (Council Conclusions..., 2016, p. 10); realization of support programmes and projects.

8. Strengthening political dialogue between EU and NATO - regular formal and informal PSC-NAC meetings, strengthening "cross briefings to respective Committees and Councils" (Council Conclusions..., 2016, p. 10).

9. Staff to staff cooperation - strengthening staff to staff interaction by means of regular meetings, at various levels, establishing contact-points 
in the EU and NATO to ensure better communication (Council Conclusions..., 2016, p. 11).

However, the realization of these ambitious tasks depends on many factors. One of them is the political will of the member states, particularly those which still treat both organizations as a forum for promoting particular interests, which do not agree upon their stance, or which do not present a unified position on important matters. These polarities are related to e.g. an idea for the desired degree of autonomy of the common security and defense policy, the importance of transatlantic ties and NATO's leading role in ensuring European security (Ignatiuk, 2016).

Operations led by NATO and the EU suggest that certain European countries have significantly lost their ability to conduct operations in crisis situations. This is mainly due to a great reduction in defense funding - an element that causes exacerbation of mutual transatlantic relations, particularly with the US. The technological advantage of the US over other member states is increasing. Therefore the question remains whether the country will be still interested in cooperation with its European allies as the US involvement in this region is gradually falling. It has been particularly visible during Donald Trump's presidency ${ }^{11}$. US withdrawal from Europe would mean a deep crisis in security. Stabilization in Europe is still based on the military power of the US and the protection of American nuclear umbrella. With the growing threat from Russia as well as international terrorism, it would be a great mistake to weaken transatlantic ties. Thus conflicting interests, and particularly the destructive behaviour of certain states can affect various trends in common security policy followed by the EU and the Alliance. A pessimistic, extremely unfavorable scenario assumes the growing divergence of interests between EU member states and NATO allies, which would lead to weakening of cohesion and solidarity, or even to the collapse of these organizations. This would mean a progressive decline in the level of Atlantic and global security, expressed primarily by return to the policy of power and pressures, as well as a rising number of internal and international conflicts, lessened respect for international law, and decreasing influence of other international organizations, such as the UN. In turn, the withdrawal of the US from political, military and economic involvement in Europe would lead to European countries being left alone and, as a result, to the weakening and even collapsing

${ }^{11}$ During the G-7 Summit held in Canada in June 2018, US President Donald Trump criticized allies from NATO and the EU in a series of tweets, accusing them of unfair trade practices and insufficient defense spending. 
of their defense system, which is still based on strategic relations with Washington. Such a situation would force intensification of activities related to individual European countries - or groups of countries associated in new institutions building their own defense capabilities, which would be a long-term and very costly process. However, there should be hope that in the future the EU-NATO cooperation will develop with a view to integration, favorable for Europe's security in all dimensions, particularly the military one. Therefore what comes out as significant is to pursue a coherent development strategy of cooperation between the EU and NATO in order to improve strategic collaboration and mutual support. The EU should be still developing its security and defence policy. However, this process must be complementary, not competitive, to NATO, e.g. through duplication the functions and structures. Both organizations should also have a clear vision of their role in the transatlantic and international security system, which will also positively influence their mutual relations.

It should be therefore expected that EU cohesiveness and capability to act in the international arena will be maintained, there will be further strengthening of NATO's power and credibility, the EU-NATO cooperation will be intensified, and US political-military presence in Europe will be continued. This is the most probable scenario, based on the hypothesis that despite some moments of crisis, the EU and the Alliance will be still developing and unquestionably contributing to the process of building peace and security.

\section{Conclusions}

The presented information leads to the conclusion that the EU and NATO are not only the most significant security and cooperative institutions in the Euro-Asian region but also key subjects in terms of global security. This is mostly a result of convergent catalogue of interests and strategic goals, shared values and complementary operationability of the member states, the majority of which belong to both organizations. These factors determine continuation and intensification of cooperation between the EU and NATO. Strengthening of the partnership is necessary due to new complex challenges and threats emerging in the currently unstable security environment - challenges that neither NATO nor the EU would be able to face alone. By working together the organizations are able to use different instruments to efficiently defend their citizens and increase European and global stability. Thus efficient functioning of these organizations depends on common and coherent security policy, so strengthening effective cooperation is 
a necessity and nowadays seems more important than in the past. With cooperation, organizations have more capabilities and resources at their disposal when reacting to a variety of crisis situations, and they can achieve a desired synergistic effect. The need to cooperate also emerges in the context of the so-called comprehensive approach to security, which frequently requires not only military or political but also civil means, and it is the EU that has most of the latter. However, the organizations should cooperate in the spirit of complementarity, fully respecting the institutional framework as well as inclusivity and decisionmaking autonomy of both structures. Stronger EU means stronger NATO, and more powerful NATO means more influence on shaping world peace and order. Thus the time has come to invest this strategic partnership with fresh impetus and new meaning.

\section{REFERENCES}

Council Conclusions on the Implementation of the Joint Declaration by the President of the European Council, the President of the European Commission and the Secretary General of the North Atlantic Treaty Organization [Annex to the Declaration]. (2016). Retrieved from http://data.consilium.europa.eu/doc/document/ST-15283-2016-INIT/ en/pdf

Czulda, R. (2013). Wyzwanie dla NATO: postępujący rozłam potencjałów. In R. Czulda, R. Łoś \& J. Reginia-Zacharski (eds.), NATO wobec wyzwań wspótczesnego świata (pp. 345-353). Warszawa: Instytut Badań nad Stosunkami Międzynarodowymi.

Dawidczyk, A. (2001). Nowe wyzwania, zagrożenia i szanse dla bezpieczeństwa Polski u progu XXI wieku. Warszawa: AON.

Deklaracja końcowa szczytu NATO w Warszawie Wydana przez Szefów Państw i Rządów uczestniczących w posiedzeniu Rady Północnoatlantyckiej w Warszawie w dniach 8 i 9 lipca 2016 r. (2016). Bezpieczeństwo Narodowe, I-IV, 215.

Deklaracja szczytu walijskiego złożona przez Szefów Państw i Rządów uczestniczących w posiedzeniu Rady Północnoatlantyckiej w Walii 5 września 2014 r. (2014). Biuro Bezpieczeństwa Narodowego (tłumaczenie robocze), Retrieved from https://www. bbn.gov.pl/ftp/dok/Deklaracja\%20szczytu\%20walijskiego.pdf

European Reassurance Initiative. (2016). Departament Obrony USA. Retrieved from http://comptroller.defense.gov/Portals/45/Documents/defbudget/fy2016/FY2016_ ERI_J-book.Pdf

Huzarski, M. (2009). Zmienne podstawy obronności i bezpieczeństwa państwa. Warszawa: AON.

Ignatiuk, A. (2016). NATO i UE wobec zagrożeń hybrydowych - nowe otwarcie we wzajemnej współpracy? Bezpieczeństwo Narodowe, 1-4, 86-97. 
Juszczak, A. (2014). NATO następnej dekady - uwarunkowania i możliwości. Bezpieczeństwo Narodowe, I, 141.

Kuźniar, R. (2004). Europejska Strategia Bezpieczeństwa. Polska w Europie, 2, 9.

Lis, E. (2016). Rola UE i NATO w systemie bezpieczeństwa międzynarodowego. Annales UMCS 63, sec. G, 1, 124-128.

NATO. (2010). Active Engagement, Modern Defence: Strategic Concept for the Defence and Security of the Members of the North Atlantic Treaty Organization. Adopted by Heads of State and Government at the NATO Summit in Lisbon 19-20 November 2010. Retrieved from https://www.nato.int/nato_static_fl2014/assets/pdf/pdf_publications/20120214_strategic-concept-2010-eng.pdf

SIPRI Yearbook. (2013). Armaments, Disarmament and International Security. Oxford: Oxford University Press.

Spotkanie Rady Europejskiej w Laeken 14-15 grudnia 2001 r. Wnioski Prezydencji. (2001). Retrieved from https:/oide.sejm.gov.pl/oide/images/files/dokumenty/konkluzje/ laeken 200112.pdf

Stańczyk, J. (2009). Grupy bojowe jako instrument polityki reagowania kryzysowego Unii Europejskiej. Studia Europejskie, 4, 38-39.

Strategia bezpieczeństwa narodowego Rzeczypospolitej Polskiej. (2014). Warszawa: BBN. Terlikowski, M., \& Chapell, G. (2011). Turcja w Sojuszu Północnoatlantyckim i jej stanowisko wobec polityki bezpieczeństwa i obrony Unii Europejskiej. Sprawy Międzynarodowe, 4, 22-36.

Traktat o Unii Europejskiej podpisany w Maastricht dnia 7 lutego 1992 r. Retrieved from http://oide.sejm.gov.pl/oide/images/files/dokumenty/traktaty/Traktat_z_Maastricht_PL_1.pdf

Traktat Północnoatlantycki sporządzony w Waszyngtonie dnia 4 kwietnia 1949 r. Retrieved from http://dziennikustaw.gov.pl/du/2000/s/87/970n

Traktat z Lizbony zmieniający Traktat o Unii Europejskiej i Traktat ustanawiający Wspólnotę Europejską podpisany w Lizbonie dnia 13 grudnia 2007 r. Retrieved from http://prawo.sejm.gov.pl/isap.nsf/DocDetails.xsp?id=WDU20092031569

Wspólna wizja, wspólne działanie: Silniejsza Europa. Globalna strategia na rzecz polityki zagranicznej i bezpieczeństwa Unii Europejskiej. (2016). Retrieved from https://europa.eu/globalstrategy/sites/globalstrategy/files/eugs_pl_version.pdf 